\title{
Dental Care Management: Till We Bid Farewell to Covid-19
}

\author{
*Pushkar Manandhar1, Sajana Shrestha Manandhar²
}

\author{
Author Info: \\ ${ }^{1}$ Assistant Professor, \\ Department of Orthodontics \\ and Dentofacial Orthopedics, \\ Peoples' Dental College and \\ Hospital \\ 2Dental Surgeon Oral and \\ Dental Clinic, Kathmandu, \\ Nepal
}

\section{*Corresponding Author: \\ Dr. Pushkar Manandhar; Email/Contact:}

dr.pushkar.manandhar@gmail.com 00977-9841489384

\begin{abstract}
The sudden outbreak of coronavirus disease 2019 (COVID-19) from Wuhan, China shook the whole world. Even though the overall mortality rate of the disease is $3.4 \%$ the exponential spread of the virus from China to other parts of the earth got the world into an abnormal global public health crisis. Despite the global effort to control the widespread of the disease, the community spread has been out of hand and declared pandemic with a public health emergency of international concern. The worst is the treatment and vaccine have not been found to date. The Health Professionals have been working day and night on the front line to fight against the virus risking their own life. The oral health professionals, on the other hand, are at the highest risk due to the aerosols produced by saliva droplets. The possibility of the spread of these saliva droplets by inhalation, contamination with skin or mucous membranes, lodgments on the surfaces of the dental offices, or other dental materials used during the dental appointments and/or even the hand contamination could be a big threat to dental professionals. They are in risk not only they get infected but also become a carrier of the virus helping in the spread of it. Thus, this article intends to provide a brief introduction, symptoms and transmission routes of this novel infection along with specific recommendations for oral health practitioners for patient screening and management protocol, and infection control strategies.
\end{abstract}

Keywords: coronavirus, COVID-19, dental, dentist, healthcare professionals, Nepal

Article Info
How to cite this article in Vancouver Style?
Manandhar P, Manandhar SS. Dental Care Management: Till We Bid Farewell to Covid-19.Europasian
J Med Sci. 2020;2(1):69-73. https://doi.org/10.46405/ejms.v2i1.48
Disclaimer




\section{INTRODUCTION}

The sudden outbreak of coronavirus disease 2019 (COVID-19) from Wuhan, China shook the whole world Even though the overall mortality rate of the disease is $3.4 \%^{1,2}$, the exponential spread of the virus from China to other parts of the earth got the world into an abnormal global public health crisis. Despite the global effort to control the widespread of the disease, the community spread has been out of hand and declared pandemic with a public health emergency of international concern. The worst is the treatment and vaccine have not been found to date. The Health Professionals have been working day and night on the front line to fight against the virus risking their own life. The oral health professionals, on the other hand, are at the highest risk due to the aerosols produced by saliva droplets. ${ }^{3}$ The possibility of the spread of these saliva droplets by inhalation, contamination with skin or mucous membranes, lodgments on the surfaces of the dental offices, or other dental materials used during the dental appointments and/or even the hand contamination could be a big threat to dental professionals. ${ }^{4}$ They are in risk not only they get infected but also become a carrier of the virus helping in the spread of it. Thus, this article intends to provide a brief introduction, symptoms and transmission routes of this novel infection along with specific recommendations for oral health practitioners for patient screening and management protocol, and infection control strategies.

Corona Virus Disease (Covid-19) is a zoonotic infectious disease caused by a newly discovered coronavirus. The etiological agent responsible for (COVID-19) is SARS-CoV-2, a positive-sense RNA virus belonging to the family Coronaviridae ${ }^{5}$. To date, there are seven known types of human coronaviruses. Four types (229E, NL63, OC43, and HKU1) are common and cause mild to moderate respiratory infections, like the common cold. Two types, Severe Acute Respiratory Syndrome coronavirus (SARS-CoV) and the Middle East Respiratory Syndrome coronavirus (MERS-CoV), can cause severe respiratory infections., 5 Since the published genome sequence for this novel coronavirus has a close resemblance with other B-Coronaviruses such as SARS-CoV and MERS-CoV, the Coronavirus Study Group of the International Committee on Taxonomy of Viruses has given its scientific name as SARS-CoV-2, even though it is popularly called COVID-19 virus. ${ }^{6,7}$
As SARS-CoV-2 is transmitted through aerosol particles ${ }^{8}$, not only the oral health professionals are at a high-risk healthcare-associated infection, but they also can become a potential carrier of the disease. As the dental procedure, be it root canal treatment or any other surgical procedure, needs the intervention of high-speed dental hand-piece which imparts the splatters of aerosols. ${ }^{9,} 10$ If proper measures of precautions are not taken; possible cross-contamination can help in the wide spread of the disease risking the friends and family of both the patient and oral health professionals. Hence, it is very much mandatory for oral health professionals to be prepared to diagnose a possible COVID-19 infection and refer them to the authorized center as soon as possible. And if emergency treatment is to be done, the professionals including the dental assistants should be well prepared with all the necessary protection.

\section{SYMPTOMS}

Although Covid-19 may be asymptomatic at times, patients usually present with clinical symptoms of fever, cough and myalgia with productive sputum. ${ }^{11}$ As the disease progresses, sore throat, headache and shortness of breath can also be experienced. Some patient even experiences diarrhea and nasal decongestion ${ }^{12}$. The most common patterns on chest computed tomography were ground-glass opacity and bilateral patchy shadowing. These cases may go undiagnosed at times as $80 \%$ of the patient has only mild symptoms resembling flulike symptoms..$^{13}$ So it is very important to have a detailed history of the patient for a confirmed diagnosis. The patient with a travel history to Wuhan or any of the pandemic area should be quarantined at least 14-21 days as the incubation period of COVID-19 disease varies from 3-14; however, it differs from person to person. ${ }^{14}$

\section{ROUTES OF TRANSMISSION}

There are two routes of transmission of novel coronavirus ${ }^{15}$. The first one is a direct transmission which includes cough, sneeze, and droplet inhalation transmission. The studies have confirmed the presence of SARS-CoV-2 in human saliva ${ }^{16}$ salivary glands are highly concentrated with angiotensinconverting enzyme 2 (ACE-2) positive cells. And it is known that SARS-CoV-2 can bind to human (ACE-2) positive cells. ${ }^{17,18}$ Therefore, coughing or sneezing by an infected person can transmit and infect individuals within a radius of approximately 6 feet. ${ }^{3,21}$ This is the reason for the recommendations of social distancing. 
Another route of transmission is contact transmission which includes contact with oral, nasal, and eye mucous membranes ${ }^{15}$. Some researchers suggest the transmission of $\mathrm{nCoV}-19$ is not limited to the respiratory tract, but the eye exposure may provide an effective way for the virus to enter the body $^{16}$.

Besides these, another important route of transmission is if droplets of SARS-CoV-2 land on inanimate objects located nearby an infected individual and are subsequently touched by other individuals $^{19}$ known as fomite transmission. A recent report suggests that the virus remains viable for up to 9 days when it is on a hard surface such as plastic or metal ${ }^{20,21}$. Thus, the disinfection of objects and hand washing is emphasized to slow down the spread of this disease.

As the main route of transmission of the virus is via respiratory droplets, aerosols, and direct contact, dental practitioners and personnel are considered a high-risk group ${ }^{16}$.

\section{DENTAL PATIENT MANANGEMENT}

On 16 th $^{\text {March 2020, the American Dental }}$ Association recommended that dentists postpone elective procedures for the next three weeks and instead only provide treatment for dental emergencies. Since the dentistry is considered as a high-risk profession, certain specific measures should be included in dental patient management.

\section{Patient Screening and triaging}

a. When a patient enters the clinic, the patient must be given a surgical or face mask and should be asked to use sanitizer. A distance of six feet should be maintained in the clinic with each other/dental personnel ${ }^{21}$. Then the body temperature should be recorded with contact-free forehead thermometer ${ }^{22}$. Next, a thorough medical history with the screening form (fig 1) should be precisely filled ${ }^{23}$.

Suspected COVID-19 patients with positive responses should be taken seriously and elective dental care should be deferred for at least two

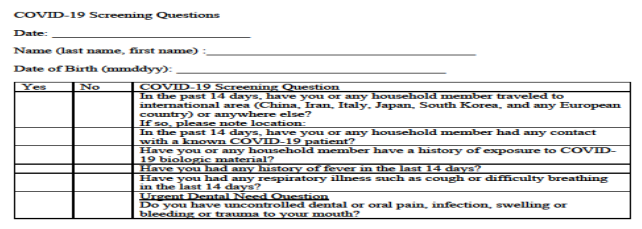

Figure 1. COVID-19 screening form ${ }^{23}$ weeks and referred to the nearest infection control department immediately. Pharmacological management and close follow up using telephone or video conferencing can be done as an urgent care in case of acute pain and/or swelling. If emergency care is to be given to the patient, such as dentoalveolar trauma or progressive space infections, then the dental treatment should be performed with proper protective equipment (PPE) in negative pressure room or Airborne Infection Isolation Rooms (AIIRs) ${ }^{23}$ Figure 1. COVID-19 screening form ${ }^{23}$

\section{Recommendation for dental care}

In case of dental emergencies as mentioned above and in the patient with NO suspicion of COVID-19, the dentists should be aware of following recommendations:

a. Basic hygiene rules:

Wash your hands when you begin your day and between each patient ${ }^{24}$. Do not wear jewelry, watch and other cosmetics like nail polish as they can harbor micro-organisms. Nails should be cut short.

b. Use Personal protective equipment ${ }^{25}$

- Gown with simple designs, if possible with long sleeves.

- Masks of type II or IIR. They must be changed for each patient, and also if they get wet as they lose their barrier effect. Never put them in your pocket or near your neck because they will be contaminated with fluids from the patient.

- Latex or nitrile gloves, to be changed after each patient, or if they break. If the procedure exceeds 30 minutes,

the gloves must be changed since they lose their barrier effect.

- Disposable caps.

- $\quad$ Safety glasses. It is mandatory to protect your eyes as they are an open wound. To avoid splashing on your face mask, visors instead of glasses can be used and this must be changed too.

c. Use of rubber dam It has been reported that rubber dam use has reduced airborne particles by $70 \%$ in around approximately 3 foot diameter ${ }^{22}$. So it is recommended to use rubber dam with high volume evacuators (HVE). In case of 
inability to use rubber dam, the use of hand instruments, e.g., hand scalers/curettes, carisolv are recommended. $\underline{2} 6$

d. Mouth-Rinsing Before Dental Treatment

A pre-procedural mouth rinse containing hydrogen peroxide is recommended over the chlorhexidine mouthwash as the virus is quite sensitive to oxidation. ${ }^{27}$ The use of mouth rinse cannot stop the transfer of the virus from dental personnel to patient or vice versa but can significantly reduce the number of micro-organisms in contact with blood during the dental procedure. ${ }^{24}$ Pre-procedural mouth rinse with $0.2 \%$ povidone-iodine might also reduce the load of coronaviruses in saliva. ${ }^{28-31}$

3. Recommendation for dental Office sterilization

It was found that human coronavirus can survive on inert surfaces up to 9 days at room temperature. ${ }^{20,21}$ Therefore, dental chair-side surfaces should be disinfected using chemicals recently approved for COVID-19 and maintain a dry environment to slow down the spread of SARS-CoV-2 ${ }^{29}$. The disposable material should be used to protect surfaces in practice (dental chair covers, drapes on countertops, barrier film over handles, radiography machine covers, etc.) Bleach can be used for furniture, as well as for cleaning floors. It is advised to start with the cleanest equipment and then to the most contaminated. The dental chair along with other inanimate surfaces in the office should be disinfected using ethanol $70 \%$ between the patients. ${ }^{25}$

\section{Removal of Medical/Dental Waste}

Medical and dental waste along with protective equipment from the office should be collected and transferred timely to a temporary storage area. Infectious waste from the treatment of the suspected or confirmed COVID case should be packed in a double-layered yellow color medical waste package bags and disposed of accordingly ${ }^{15}$.

\section{CONCLUSION}

Since its outbreak in December 2019 from Wuhan to other parts of the world, coronavirus has created chaos amongst the human being as it causes lethal respiratory infections. The number of infected along with the rate of death has no sign of stopping but increasing day by day in about 200 countries around the world, and the majority of the countries have announced lockdown and even curfews.

Even during this pandemic condition, some dental clinics are giving dental health services to needy patients putting their health at risk. The oral health professional not only should protect themselves with complete personal protective equipment but should also thoroughly evaluate and triage each patient to avoid cross-contamination. If a patient is to be intervened then try to limit the aerosolproducing procedures. Proper handwashing and mouth rinsing of the patient may reduce the risk, The proper disinfection of the dental office and proper dental and medical waste management should be encouraged to break the chain of crossinfections.

We hope these guidelines will be of great assistance to all dental professionals in protecting each other and helping impede the spread of the virus furthermore. These are fundamental recommendations that should be followed by all the dental practitioners in their daily activities until we bid farewell to COVID-19.

\section{REFERENCES}

1. Sohrabi C, Alsafi Z, O'Neill N, Khan M, Kerwan A, AlJabir A, et al. World Health Organization declares global emergency: A review of the 2019 novel coronavirus (COVID- 19). Int J Surg 2020;76:71-76. https://doi. org/10.1016/j.ijsu.2020.02.034 Google Scholar | PMC | PubMed | CrossRef | FullText

2. WHO Director-General's opening remarks at the media briefing on COVID-19 - 3 March 2020 [Internet]. Full Text

3. Yamada H, Ishihama K, Yasuda K, Hasumi-Nakayama Y, Shimoji S, Furusawa K. Aerial dispersal of bloodcontaminated aerosols during dental procedures. Quintessence Int. 2011; 42(5):399-405. Google Scholar | Full Text

4. COVID-19 OUTBREAK: GUIDANCE FOR ORAL HEALTH PROFESSIONALS [Internet]. FDI World Dental Federation. 2020. Full Text

5. Gorbalenya, A.E., Baker, S.C., Baric, R.S. et al. The species Severe acute respiratory syndrome-related coronavirus: classifying 2019-nCoV and naming it SARS-CoV-2. 2020 Apr;5(4):536-544. https://doi.org/10.1038/s41564-0200695-z Google Scholar| Pub Med | PMC| Cross Ref | Full Text

6. Wax RS, Christian MD. Practical recommendations for critical care and anesthesiology teams caring for novel coronavirus (2019-nCoV) patients. Can Can J Anaesth. 2020 May;67(5):568-576. https://doi.org/10.1007/ s12630-020-01591-x Google Scholar| Pub Med | PMC | Cross Ref | Full Text

7. Zhu N, Zhang D, Wang W, Li X, Yang B, Song J, et al. A Novel Coronavirus from Patients with Pneumonia in 
China, 2019. N Engl J Med 2020;382:727-733. https:// doi.org/10.1056/NEJMoa2001017 Google Scholar| Pub Med| PMC| Cross Ref | Full Text

8. Peng $X, X u X, L i Y$, Cheng $L$, Zhou $X$, Ren B. Transmission routes of 2019-nCoV and controls in dental practice. Int J Oral Sci. 2020; 12(1):9. https://doi.org/10.1038/ s41368-020-0075-9 Google Scholar | Pub Med| PMC | Cross Ref | Full Text

9. Sawhney A, Venugopal S, Babu GR, Garg A, Mathew $M$, Yadav $M$, et al. Aerosols how dangerous they are in clinical practice. J Clin Diagn Res. 2015;9(4):ZC527. https://doi.org/10.7860/JCDR/2015/12038.5835 Google Scholar | Pub Med | PMC | Cross Ref | Full Text

10. Kobza J, Pastuszka JS, Bragoszewska E. Do exposures to aerosols pose a risk to dental professionals? Occup Med (Lond). 2018; 68(7):454-8. https://doi.org/10.1093/ occmed/kqy095 Google Scholar | Pub Med | PMC | Cross Ref | Full Text

11. Wu Z, McGoogan JM. Characteristics of and Important Lessons From the Coronavirus Disease 2019 (COVID-19) Outbreak in China: Summary of a Report of 72314 Cases From the Chinese Center for Disease Control and Prevention. JAMA. 2020 Feb 24. https://doi. org/10.1001/jama.2020.2648.Google Scholar | Pub Med | Cross Ref | Full Text

12. Amgain K, Neupane S, Panthi L, Myths vs truths regarding the Novel Coronavirus Disease (COVID-19) Outbreak. Journal of Karnali Academy of Health Sciences 2020; 3 (1): 1-6. https://doi.org/10.3126/jkahs. v3i1.28367 Google Scholar | Full Text

13. Situation Report-56 SITUATION IN NUMBERS total and new cases in last 24 hours [Internet]. [cited 2020 Mar 16]. Full Text

14. Backer JA, Klinkenberg D, Wallinga J. Incubation period of 2019 novel coronavirus (2019-nCoV) infections among travellers from Wuhan, China, 2028 January 2020. Euro Surveill. 2020;25(5) https://doi. org/10.2807/1560-7917.ES.2020.25.5.2000062 Google Scholar | Pub Med | PMC | Cross Ref | Full Text

15. To KK-W, Tsang OT-Y, Yip CC-Y, Chan K-H, Wu T-C, Chan JM-C, et al. Consistent Detection of 2019 Novel Coronavirus in Saliva. Clin Infect Dis. 2020.149 https:// doi.org/10.1093/cid/ciaa149.Google Scholar | Pub Med | PMC | Cross Ref| Full Text

16. Hoffmann $M$, Kleine-Weber $H$, Schroeder $S, M u ̈ ~ M A$, Drosten C, Pö S, et al. SARS-CoV-2 Cell Entry Depends on ACE2 and TMPRSS2 and Is Blocked by a Clinically Proven Protease Inhibitor Article SARS-CoV-2 Cell Entry Depends on ACE2 and TMPRSS2 and Is Blocked by a Clinically Proven Protease Inhibitor. Cell 2020. pii: S0092- 8674(20)30229-4. https://doi.org/10.1016/j. cell.2020.02.052 Google Scholar | Pub Med | PMC | Cross Ref | Full Text

17. Sabino-Silva R, Jardim ACG, Siqueira WL. Coronavirus COVID-19 impacts to dentistry and potential salivary diagnosis. Clin Oral Investig. 2020 Apr;24(4):1619-1621. https://doi.org/10.1007/s00784-020-03248-x Google Scholar | Pub Med | PMC | Cross Ref | Full Text

18. Transmission of Coronavirus Disease 2019 (COVID-19) | CDC [Internet]. [cited 2020 Mar 9]. Full Text
19. Kampf G, Todt D, Pfaender S, Steinmann E. Persistence of coronaviruses on inanimate surfaces and its inactivation with biocidal agents. J Hosp Infect 2020;104:246-51. https://doi.org/10.1016/j.jhin.2020.01.022_Google Scholar | Pub Med| PMC | Cross Ref | Full Text

20. Centers for Disease control and Prevention, Infection control: severe acute respiratory syndrome coronavirus 2 (SARS-CoV-2). Full Text

21. Samaranayake, L. P., Reid, J. \& Evans, D. The efficacy of rubber dam isolation in reducing atmospheric bacterial contamination. ASDC J. Dent. Child 01 Nov 1989, 56(6):442-444 Google Scholar| Full Text

22. Amber Ather, BDS, DDS1, Biraj Patel, BDS1, Nikita B. Ruparel, MS, DDS, PhD1, Anibal Diogenes, DDS, MS, PhD1 and Kenneth M. Hargreaves, DDS, PhD1Coronavirus Disease 19 (COVID-19): Implications for Clinical Dental Care Journal of Endodontics 46(5): in press, 2020. https://doi.org/10.1016/j.joen.2020.03.008 Google Scholar | Pub Med | Cross Ref | Full Text

23. Larson EL, Early E, Cloonan P, Sugrue S, Parides M. An organizational climate intervention associated with increased handwashing and decreased nosocomial infections. Behav Med. 2000; 26(1):14-22. https://doi org/10.1080/08964280009595749 Google Scholar Pub Med | Cross Ref | Full Text

24. Parhizkar A, Shamszadeh S, Mardani M, Asgary S. Dental Considerations After the Outbreak of 2019 Novel Coronavirus Disease: A Review of Literature, Arch Clin Infect Dis. Online ahead of Print ; In Press(In Press):e103257.Google Scholar | Full Text

25. Kathuria V, Ankola AV, Hebbal M, Mocherla M. Carisolvan innovative method of caries removal. J Clin Diagn Res. 2013;7(12):3111-5. Google Scholar | Pub Med | PMC | Full Text

26. Jin $Y H$, Cai $L$, Cheng ZS, Cheng $H$, Deng $T$, Fan $Y P$, et al. A rapid advice guideline for the diagnosis and treatment of 2019 novel coronavirus (2019-nCoV) infected pneumonia (standard version). Mil Med Res. 2020;7(1):4 Google Scholar | Pub Med | PMC | Cross Ref | Full Text

27. Fine $D H$, Furgang $D$, Korik I, Olshan $A$, Barnett $M L$, Vincent JW. Reduction of viable bacteria in dental aerosols by preprocedural rinsing with an antiseptic mouthrinse. Am J Dent. 1993; 6(5):219-21. Google Scholar| Full Text

28. United States Environmental Protection Agency Washington, D.C. 20460 Office Of Chemical Safety And Pollution Prevention List N: EPA's Registered Antimicrobial Products for Use Against Novel Coronavirus SARS-CoV-2, the Cause of COVID-19

29. Fehr AR, Perlman S. Coronaviruses: An overview of their replication and pathogenesis. Methods Mol Biol. 2015; 1282:1-23. https://doi.org/10.1007/978-1-4939-243871 Google Scholar | Pub Med | PMC | Cross Ref | Full Text

30. Worldometer. Countries where COVID-19 has spread. 2020. Full Text 